"If you become a slave here, do you think they're going to fight there?" Tamil Diaspora Mobilizations and Host-country Politics

\title{
Lola Guyot
}

\section{OpenEdition}

\section{Journals}

Electronic version

URL: https://journals.openedition.org/samaj/7665

DOI: $10.4000 /$ samaj.7665

ISSN: $1960-6060$

Publisher

Association pour la recherche sur l'Asie du Sud (ARAS)

\section{Electronic reference}

Lola Guyot, "'If you become a slave here, do you think they're going to fight there?" Tamil Diaspora

Mobilizations and Host-country Politics", South Asia Multidisciplinary Academic Journal [Online], 27

2021, Online since 24 November 2021, connection on 15 March 2022. URL: http://

journals.openedition.org/samaj/7665 ; DOI: https://doi.org/10.4000/samaj.7665

This text was automatically generated on 15 March 2022.

\section{c)}

This work is licensed under a Creative Commons Attribution-NonCommercial-NoDerivatives 4.0

International License. 


\title{
"If you become a slave here, do you think they're going to fight there?" Tamil Diaspora Mobilizations and Host-country Politics
}

\author{
Lola Guyot
}

\section{Introduction}

1 While numerous authors have looked at the relation between "diaspora politics" ${ }^{1}$ and the political environment of migrants' host-countries, they have mostly focused on the strategic adaptation of diaspora activists to their immediate political context (see for instance Østergaard-Nielsen 2003; Massicard 2007, 2013; Koinova 2010, 2011; Baser 2015; Sökefeld 2016; Orjuela 2018). ${ }^{2}$ Beyond this strategic dimension, the issue of the relations between diaspora politics and migrants' broader political inclusion in their country of settlement is rarely addressed. By political inclusion, in this article I do not refer to the provision of political rights and opportunities to immigrants by the host-society, but to the socialization of migrants to political norms and causes encountered in their host-country ${ }^{3}$ and to their participation in the political affairs of that host-country. ${ }^{4}$ These dynamics are often framed by scholars in terms of "political integration" (Bauböck et al. 2006; Giugni and Morales 2011; Hellgren 2015; Penninx and Garcés-Mascareñas 2016), but the concept tends to convey the idea of a passive process of conforming to a political status quo which runs counter to the article's objective of studying the modalities of assertion of migrants as political agents in their country of settlement, whereby they contribute to the political evolution of their host-society as much as the host-society influences their own political trajectory. I will therefore use the more neutral terms of political inclusion.

2 In the academic literature, diaspora politics, "immigrant politics"-namely mobilizations to improve immigrants' own social, economic, or legal situation in their 
country of settlement (Østergaard-Nielsen 2003:762)-and migrants' political participation in host-country mainstream politics are most often studied in isolation (Waldinger and Duquette-Rury 2016). Amongst the few studies focusing on the links between these different types of mobilization, some authors have argued, in line with assimilationist perspectives, that transnational political loyalties are an obstacle to migrants' social, cultural, and political inclusion in their host-country (Huntington 2004; Berger, Galonska and Koopmans 2004; Cain and Doherty 2006; Staton, Jackson, and Canache 2007). ${ }^{5}$ But most scholars have on the contrary insisted on the cumulative nature of the two processes. In particular, several authors have shown that the skills and resources that migrants acquire in their transnational political practices can be transferred into their engagement in the host-country public arena (Guarnizo, Portes and Haller 2003; Escobar 2004; Portes and Rumbaut 2006; Morales and Morariu 2011; Gershon and Pantoja 2014). Even though the two fields or research remain largely separated, a few scholars have looked more specifically at the links between diaspora politics and immigrant politics. Some of them noted that, with time, migrants' activism tends to evolve from homeland-oriented politics to immigrant politics (Østergaard-Nielsen 2003; Lacroix 2005; Zederman 2018). ${ }^{6}$ But as highlighted by some scholars, the two can also be concomitant or merged. For example, when migrants coming from minorities persecuted in the homeland demand to be recognized as a distinct cultural group in their receiving state, they ask for specific cultural rights as immigrants while sending a strong signal to the homeland regime (ØstergaardNielsen 2003). Homeland politics can also be a leverage tool for immigrant politics, when migrants' nationalist engagement in the liberation of their homeland also enables them to ask for equality of treatment and symbolic recognition in their country of settlement (Dusenbery 1995; Jüergensmeyer 1997; Gayer 2002).

3 Some scholars have therefore analyzed the links between diaspora politics and other forms of political engagement in host countries-in particular immigrant politics-and have shown that transnational mobilizations and political inclusion are not a zero-sum game. What these studies have not analyzed in depth, though, is what a broader politicization in the host-country means for diaspora activists themselves, and the potential debates and tensions around this issue within a diasporic political field. As explained by Lacroix (2019), the moral economy ${ }^{7}$ that underpins relations between migrant and non-migrant populations, combined with feelings of guilt common amongst exiles, assigns to migrants some moral obligations towards non-migrants. When they are embraced by diasporic political structures, these moral obligations inform and constrain the way migrants engage politically in their host-country. The objective of this article is then to explore how diaspora activists engaged in a struggle at home negotiate their political concerns in their country of residence. It addresses these questions through the analysis of Tamil diasporic mobilizations during and after the Sri Lankan civil war.

4 The Sri Lankan civil war, which lasted from 1983 to 2009, opposed the Liberation Tigers of Tamil Eelam (LTTE), a Tamil guerrilla group fighting for the creation of a separate state, to the Sri Lankan government, supported by the Sinhalese majority. It ended in 2009 with the annihilation of the LTTE and the massacre of thousands of Tamil civilians. The post-war situation is characterized by a triumphalist state discourse denying the massacres, the militarization of the Tamil regions, widespread human rights violations, and the systematic repression of Tamil critical voices. The war drove hundreds of thousands of Tamil refugees into exile. Joining previous Tamil emigrants, 
they formed a large diaspora of about a million people, which today represents about $40 \%$ of the indigenous Tamil population in Sri Lanka. Tamil migrants are primarily based in the state of Tamil Nadu in South India, Canada, Europe, Australia, and the United States (ICG 2010). Their socio-economic status varies depending on the hostcountry and on the conditions of their migration. In western countries, on which this paper focuses, a difference exists between migrants from the first wave of migration, who fled Sri Lanka before the 1990s, came from a relatively high social and caste background, and settled in priority in the UK and Canada, and those from the second wave of migration, who came from a lower socio-economic and caste background and often settled in non-English speaking countries, after the UK and Canada had closed their doors to Tamil refugees. Beyond these divisions, strong community ties have been established in all host-countries, favoring the active maintenance of a collective Tamil identity abroad (Mcdowell 1996; Fuglerud 1999; Dequirez 2007).

The Tamil diaspora has attracted the attention of political scientists due to its active involvement in the Sri Lankan conflict. From the early 1990s to 2009, the mobilization of Tamil migrants in support of the LTTE insurgency was so massive that the community is often presented as a paradigmatic case of "long-distance nationalism" (Anderson 1998). While in the early phase of the war, Tamil diaspora politics were highly diverse, in the 1990s and 2000s, the diasporic political field became largely dominated by the LTTE, which saw in the migrant community a vital source of funding. ${ }^{8}$ In order to secure financial contributions from Tamil migrants, the LTTE established its monopoly over the diasporic political field, repressing alternative voices ${ }^{9}$ and setting up a large international political apparatus under its direct control, often referred to as the Tamil Coordination Committees (TCCs). ${ }^{10}$ These structures engaged in an intense work of nationalist propaganda and in "politics of encadrement"11 of the migrant community. They managed to politicize Tamil identity abroad to the extent that it became equated with supporting the LTTE struggle for independence, those refusing to do so being depicted as traitors who had abandoned their Tamil identity (Fuglerud 1999, Etiemble 2004; Sriskandarajah 2005; Dequirez 2011; Thiranagama 2014; Guyot 2020).

6 This configuration of diaspora politics started to diversify again in the late 2000s, as the LTTE was losing military ground in Sri Lanka, and radically changed after the Tigers' defeat in 2009. While the LTTE was wiped out at home, the remnants of their structures abroad endured, but they lost their dominant status, and a myriad of new diasporic organizations emerged (Vimalarajah and Cheran 2010; Brun and Van Hear 2011; Amarasingam 2015). ${ }^{12}$ Given the repression and disempowerment of Tamil opposition forces operating in Sri Lanka, post-war Tamil diaspora politics no longer take the form of enormous support for political actors at home. Instead, they mostly consist in efforts to make international actors force the Sri Lankan government to implement measures favorable to the Tamil population and in efforts to perpetuate a commitment of the diaspora to the Tamil nationalist cause (Hess and Korf 2014; Amarasingam 2015; Gazagne and Sánchez-Cacicedo 2015; Rasaratnam 2018; Orjuela 2018， 2020; Kandasamy 2020). While the primary goal of the newly formed diasporic organizations is to lobby their host-country authorities, international organizations, and NGOs into putting pressure on the Sri Lankan authorities, a large part of the activities of the former diasporic LTTE structures are community-oriented activities aiming at keeping the "nationalist flame" alive in the diaspora. 
7 Since Tamil migrants form one of the most politically active diasporas, their mobilizations during and after the war have been widely studied. Some scholars looked more specifically at the relationship of Tamil diaspora activists with their host-country political environment, showing how the criminalization of the LTTE in the west and the rejection of Tamil separatism more broadly constrained their advocacy efforts. They analyzed how different Tamil organizations reacted to these constraints, pragmatically adapting their claims and practices to international liberal standards or sticking to a more principled approach (Wayland 2004; Nadarajah 2009, 2018; Laffey and Nadarajah 2012; Geribye 2013; Walton 2014; Amarasingam 2015; Orjuela 2018). While the issue of strategic adaptation to host-country norms has attracted the attention of scholars, existing debates amongst Tamil activists about the association of Tamil nationalism with host-country politics beyond strategic concerns have not been thoroughly analyzed. Some scholars have noted the specificities of the political engagement of second-generation Tamil migrants who, more than their elders, identify with both their host-country and the Tamil nation, and whose activism is "more firmly located in and bound to the context of the host-country" (Hess and Korf 2014:426; see also Amarasingam 2015; O'Neill 2015; Thurairajah 2013). But the tensions in the Tamil diasporic political field surrounding the issue of incorporation in host-country politics and the complex attitudes of diasporic organizations towards this question remain to be studied.

8 The article focuses on how these tensions unfold in three host-countries of Tamil diaspora activists: the UK, France, and Canada. The empirical data used in the article was collected during fieldwork conducted in London, Paris and Toronto between 2016 and 2019. The arguments developed in the article therefore do not cover the period beyond 2019. About 80 interviews ${ }^{13}$ were conducted with first and second-generation Tamil activists, who campaigned or had campaigned against the Sri Lankan regime, and who belonged to the most important pro- and anti-LTTE political organizations in each country. With a sampling approach essentially based on snowballing, I first met members of newly formed advocacy groups, and was later introduced to members of the less easily approachable LTTE structures abroad. The latter were in a prominent position in the diasporic political field but worked more covertly, with little visibility outside the Tamil community. In addition to conducting formal recorded interviews with activists, I participated in numerous community events (cultural shows, commemoration events, fundraising galas, conferences, and advocacy events), during which I had countless informal talks with organizations' sympathizers or bystanders. But my fieldwork remained focused on political activists and, as such, the arguments in this article are about the diasporic political field and not about the broader Tamil migrant population.

\section{The LTTE and the primacy of the Tamil cause}

\section{An exclusive commitment to Tamil nationalism}

9 In some respects, the diasporic organizations subordinated to the LTTE during the war, and claiming to be their successors after the war, did not encourage the broader political inclusion of Tamil activists in their host-country. The approach dictated by the LTTE leadership, and then maintained by post-war LTTE diasporic structures, promoted 
an exclusive and uncompromising engagement of migrants in the Tamil nationalist cause. It rejected alternative political endeavors as well as external ideological influences, which were seen as posing the risk of co-optation and as deviating migrants from the separatist struggle.

During the war, the LTTE promoted an absolute and exclusive dedication of migrants to Tamil nationalism. Alternative political engagements whose primary purpose was not to serve the Tamil nationalist cause-including immigrant politics-were seen as a diversion from the nationalist struggle and discouraged by LTTE diaspora activists. For example, a group like the Tamil Eelam Society, which was actively lobbying for the rights of Tamil asylum seekers in Canada in the first decade of the war, was led to stop its activities. According to one of its members, once the Tigers had established their domination over the diasporic political field, "this kind of advocacy stopped, then it was just about the cause, it became in a sense shameful to focus on people here" (interview with a former member of the Tamil Eelam Society, Toronto, 2018). The LTTE narrative of the victory to come and of the prompt return of migrants to Sri Lanka disqualified mobilizations for migrants' rights in their host-countries as vain. Migrants were blamed for having abandoned the struggle (Brun and Van Hear 2011), and the moral economy promoted by the armed movement assigned to them a duty to leave their own concerns aside to assist their counterparts fighting at home. The following words from a former head of the LTTE oversea international structure reflect this association of duty, guilt, and the primacy of the Tamil nationalist cause over migrants' personal concerns, that was promoted by the LTTE:

Tamils here have problems, many don't have a good job, they have health issues, there is a lot of mental health issues in the community. ... But it was not the role of the TCC to take care of that. We had to defend Tamils in Sri Lanka, they were the ones who were suffering. And there, they were fighting. ... We couldn't focus on the community here, on the problems here. It was not... [silence]. It wouldn't be right (interview with a former member of the Tamil Eelam Society, Toronto, 2018).

11 After the war, the remnants of the LTTE structures abroad still promoted the primacy of the Tamil cause over other political concerns. Groups that combined their nationalist commitment with other political engagements in their country of settlement were accused of not genuinely caring for the cause. In the United Kingdom, the organization Tamil Solidarity which, as we will see, was actively engaged in British politics, was for instance vividly criticized by members of the British TCC: "We receive criticisms about being too attached to politics here and not enough to the cause. Lot of people criticize us, saying we only worry about the white workers, 'you are only working with white people, that's not acceptable, why would we be part of it?' they say" (interview with a member of Tamil Solidarity, London, 2017).

Other armed national liberation movements, such as the National Liberation Front (FLN) in Algeria and the Kurdistan Workers' Party (PKK) in Turkey, also established diasporic structures promoting the idea that the struggle at home prevailed, and that this precluded any other form of political engagement for migrants. Based on the idea that all migrants would ultimately return to an independent Algeria, Algerian migrants were advised by the FLN not to take part in political movements in France, to avoid mixing with the French society and to remain focused on the fight in the homeland (Stora 1999). Any engagement of Kurdish migrants in immigrant politics in Europe was also for a long time depicted by the PKK diasporic structures as morally inappropriate given the violence faced by Kurds at home. The rival organization of the PKK in Europe, 
the Socialist Party of Kurdistan (PSK), was fiercely criticized for its activism in defense of migrants' rights while not being truly active in Turkey itself (Grojean 2008). In some cases, when the struggle in the homeland is of prime importance for diasporic organizations, the latter can therefore see the broader political participation of migrants in their host-country as problematic.

This type of movement can even see the socio-cultural integration of migrants in their host-society as potentially conductive to their demobilization and therefore strive to prevent it. During the war, the LTTE's efforts to keep Tamil migrants committed to the fight for independence led them to push for a communitarian entre-soi, structured around pro-LTTE local associations (Etiemble 2004, 2017; Dequirez 2011; Thiranagama 2014). Based on a study of Tamil LTTE associations in France, Etiemble (2017) showed that the movement encouraged the socio-economic integration of migrants, which was depicted as a "good integration", but strongly rejected dynamics of acculturation, considered as a "bad integration", turning migrants away from the nationalist cause. From the point of view of LTTE associations abroad, migrants had to "live in France while preserving a form of Sri Lankan communitarianism and dedicating themselves to the "Tamil cause"' (Etiemble 2017:71, translated from French). The point here is about the way LTTE activists conceived migrants' role rather than about the actual effects of their practices, which are difficult to assess. While the LTTE triumphalist propaganda and mobilizing efforts helped to nurture an enduring perspective of return for some migrants and might therefore have contributed to isolating them from a society they perceived as a temporary home, this was not true for many well-settled Tamils who had no intention to return to Sri Lanka. After the defeat of the LTTE in 2009, and with the fears of a government-induced extinction of Tamil culture in Sri Lanka, the preservation of a Tamil identity abroad and of Tamil nationalist feeling among migrants remained central-and even became an end in itself-for the remaining LTTE diasporic structures. But it also became more difficult for TCC activists to promote a communitarian entre-soi as hopes of a forthcoming return to an independent Tamil land withered away.

The primacy given by LTTE diaspora activists to the Tamil nationalist struggle over other political concerns did not mean that their activism was disconnected from their host-country political arena. In particular during the last decade of the war, links were built between the TCCs and local authorities in constituencies with a large Tamil population. Demonstrations in defense of the Tamil separatist cause were also regularly organized in migrants' host-countries and in front of the United Nations in Geneva (Dequirez 2011; Orjuela 2008). After the war, LTTE diasporic structures continued to organize public protests and to build connections with local politicians. Besides the creation of an independent Tamil state, their post-war demands also included a recognition that the massacres of Tamil civilians committed in 2009 amounted to genocide, and the creation of an international justice mechanism to prosecute Sri Lankan war criminals.

15 However, in contrast to independent organizations dedicated to lobbying, obtaining international supports was arguably not a priority for LTTE activists abroad. During the war, the strategy of the LTTE leadership in Sri Lanka seemed to rely on the perspective of a military victory more than on building international alliances, ${ }^{14}$ and LTTE branches abroad were asked first and foremost to raise funds for the armed struggle. According to Amarasingam (2015), until the last phase of the war, the LTTE leaders "had not 
directly asked the diaspora for anything more than financial support, despite offers from many in the diaspora to organize protests and initiate lobbying efforts. Diaspora activists were informed that the LTTE could sustain itself as long as they provided the financial support" (p. 101). In addition, the proscription of the LTTE as a terrorist organization in most Western countries in the 2000s and the criminalization of Tamil separatist demands more broadly ${ }^{15}$ made it difficult for LTTE diaspora activists to access national decision-makers. After the war, they expressed a strong defiance towards international actors, who had failed Sri Lankan Tamils and supported the "genocidal" Sri Lankan regime (interviews with members and former members of the TCCs, Paris and London, 2017-2019). All in all, the lobbying activities of LTTE diasporic structures therefore remained limited and confined to the local level.

In this context, links established during and after the war between LTTE activists abroad and host-country political actors were not conductive to a broader engagement of Tamil activists in host-country politics in the same way that it has worked out for independent organizations. Firstly, in their advocacy practices, LTTE diaspora activists were strictly impervious to ideological influences from the host-country political arena. Strategic adaptations to international liberal standards were depicted as compromission, co-optation and ideological treason. ${ }^{16}$ The need to improve their access to decision-makers was not considered to justify departures from the LTTE separatist ideology, to which LTTE structures abroad closely stuck even in their advocacy practices (Dequirez 2011). ${ }^{17}$ Even though, after the defeat of the LTTE, the advent of an independent Tamil state became highly unlikely, associations formerly subordinated to the LTTE continued to reject any modification of the "original" Tamil nationalist cause and any form of political compromise. As they strove to perpetuate the commitment of the Tamil migrant community to the Tamil cause in its "pure" and "authentic" form, they maintained an attitude of "doctrinal purity," (Amarasingam 2015:145) rejecting strategic compromises as well as deeper ideological evolution. In a similar way, until the late 1990's, PKK activists in Europe had refused to divert from the PKK's separatist ideology even though it compromised the efficiency of their advocacy efforts (Grojean 2008).

17 Secondly, the primacy given by LTTE activists to the fight for independence and their reluctance to let any other political concern interfere with this quest meant that their search for political supports in countries of settlement was devoid of considerations for the politicians' political orientation. Political actors targeted by these structures were not chosen because of their position on the host-country political spectrum, but because of their responsiveness to the Tamil cause. The local representatives with whom LTTE structures were in contact were often from left-wing political parties: the communist and ecology parties in France, Labour in the UK, and Liberals in Canada; but this was mostly linked to questions of opportunity rather than to political affinities. These parties are indeed the ones most likely to seek connections with migrant groups, and they are often elected in constituencies with large immigrant populations (interviews with members of the LTTE international structures, Paris, London and Toronto, 2018-2019). An independent activist, who worked as an advisor for different Tamil organizations in Europe, explained to me that members of post-war LTTE structures sometimes contemplated establishing connections with representatives of "nationalist" parties because of the latter's commitment to nationalist principles, and that he had to dissuade them from doing so since these parties often turned out to be extreme-right xenophobic parties (interview with an independent activist, London, 
2017). The primacy given to the Tamil nationalist cause over other political considerations in the advocacy practices of LTTE activists also showed through their participation in host-countries' national protest events. For example, when they took part in the demonstrations on Labor Day and International Women's Day, TCC activists and sympathizers did so with a focus on the Tamil struggle exclusively. They had their own procession in defense of Tamil rights in the midst of the protest, with no reference to the theme of the day.

This kind of engagement in host-country politics, in which migrants' commitment to the Tamil nationalist cause seems to supersede all other political concerns, is also sometimes visible beyond the activist sphere, when migrants make political choices directly based on their nationalist objectives. For example, as I was trying to understand the allegedly large Tamil vote for Brexit in the UK and asking people about their motivation for voting in that way, their answers often reflected a conflation of Brexit with the Tamil struggle: "We cannot have Tamil Eelam there, the struggle is crushed, they will never let us... But if we can't have our freedom there, we can have it here. ... So, we voted to leave" (interview with an LTTE sympathizer, London, 2017). An activist involved in Tamil youth associations in France explained to me that several young Tamils had told him they wanted to enroll in the French army following a similar logic: in their words, since they could not fight in Sri Lanka like their parents, they would do it in France (interview with an independent activist, Paris, 2019).

In sum, during and after the war, organizations in the Tamil diasporic political field which were affiliated to the LTTE resisted the incorporation of external ideological influences in Tamil diasporic mobilizations and the extension of the Tamil nationalist struggle to other political causes. They considered the struggle for independence in Sri Lanka as the prime objective and considered alternative political endeavors as problematic.

\section{Political assertion through recognition politics}

20 The primacy given to the Tamil cause did not mean, though, that the activism of LTTE structures abroad was not at all conductive to a broader political inclusion of activists in their country of settlement. Indeed, through their demands for self-determination or for the prosecution of Sri Lankan war criminals, LTTE diaspora activists and sympathizers asserted themselves as host-country residents with political rights and engaged in recognition politics to gain a measure of visibility and respect in their country of residence. As mentioned earlier, political inclusion should not be seen as an endorsement by migrants of the dominant political culture and values of their hostcountry. It rather amounts to their assertion as political actors, whatever the content of their demands.

21 The advocacy efforts and the protests organized by the TCCs during and after the war also aimed at challenging the delegitimization of Tamil nationalism in migrants' hostcountries. During the massive demonstrations that took place while the LTTE was being wiped out in 2009 in all countries of settlement of the diaspora, this logic was central to the decision of many Tamils to wave the LTTE flag despite the fact that it was considered as a symbol of terrorism and was said to put potential non-Tamil supporters off. As explained by a British Tamil activist: 
At the time of the protests, there were two struggles being fought: a struggle there with the LTTE, and a struggle here in the diaspora with the state. I remember the police coming and taking photographs. Every day, the police were coming, and asking to put down the flag. The mood of the time was you know: "I'm gonna hold the flag, and we're gonna do it in protest not just the Sri Lankan state but also to say this is my right as British Tamil citizen and I will hold it" (interview with a second-generation member of the Tamil Guardian, London, 2016).

During demonstrations organized after the war, some participants explained to me that they were not only protesting the oppression of the Tamil people by the Sri Lankan government. They were also protesting the criminal inaction of their own host-country government, which had done nothing to stop the massacres in 2009 and was still doing nothing to alleviate the plight of Tamils in Sri Lanka, despite demands from citizens of Tamil origin. This kind of assertion of Tamil activists as political actors in their country of residence became particularly strong with the coming of age of second-generation migrants, and with their greater political mobilization following the 2009 protests (Hess and Korf 2014). As explained by a second-generation activist in London, young Tamil activists, who were born and raised in their country of settlement, tended to be more confident and assertive of their political rights than their elders:

There is this colonial aspect, where a lot of older generations are very grateful to the UK when they receive a bit of attention, whereas the younger generations are much more confident, aware of their rights. We have the right to see our demands taken into consideration in the making of foreign policy, just like any other British citizen. ... The UK or Canada for example, they have to intervene in Sri Lanka not just because of human rights or whatever, but because it's their duty towards their Tamil population (interview with a second-generation member of the Tamil Guardian, London, 2016).

LTTE diaspora activists' demands that international actors intervene in Sri Lanka also went hand in hand with "recognition politics". These consisted in efforts to obtain some form of public endorsement from the host-country authorities, of both the Tamil nationalist cause and Tamil cultural identity, the two being tightly linked. Local Tamil associations linked to the LTTE international structure systematically invited local politicians to their commemoration events, fundraising galas, or cultural shows. NonTamil local political figures were not only-or even primarily-expected to intercede on Tamil migrants' behalf with national foreign-policy makers, but to provide some form of recognition for the Tamil nationalist narrative and the collective memory associated with it. Memory politics are central for preserving diasporic collective identities (Lacroix and Fiddian-Qasmiyeh 2013), but they are also part of migrants' struggle for recognition in their country of settlement. According to activists I interviewed, obtaining expressions of symbolic recognition abroad for the Tamil nationalist counternarrative had become even more important after the war. Since after 2009, Tamils in Sri Lanka were forced to publicly repudiate the LTTE, to endorse the regime's triumphalist narrative and were forbidden to mourn their dead (Seoighe 2017), the international arena had become a space where Tamils could freely formulate a counternarrative forbidden in the homeland. The public adoption by host-country politicians of elements of the Tamil nationalist terminology-such as the terms "Tamil nation", "Tamil Eelam" or "Tamil genocide"-was then actively sought for, carefully scanned, commented on online, and considered as a success in itself (interviews with members of the LTTE international branches, Paris, and London, 2017-2018). In constituencies with a large Tamil population, demands from Tamil associations even led to steles being erected or trees being planted in memory of the "Tamil genocide," with the 
agreement and blessing of the local authorities. Demands for public endorsement of the Tamil counter-narrative were also mixed with the promotion of Tamil culture. In Canada and the UK, Tamil activists for example engaged in campaigns for the creation of chairs of Tamil studies in the University of Toronto and the School of Oriental and Africa Studies (SOAS) (University of Toronto 2020; SOAS 2020). In Canada, Tamil politics of recognition culminated in the declaration of the month of January as "Tamil Heritage Month" in 2016 (Tamil Culture 2016). As noted by Østergaard-Nielsen (2003) about Kurdish associations in Germany, Tamil activists therefore mixed immigrant politics with diaspora politics, since their demands for recognition as a distinct cultural group in their host-country, when accepted, also sent a strong message to the Sri Lankan authorities.

In their events, pro-LTTE Tamil associations mixed host-country symbols and Tamil nationalist symbols in what can be seen as efforts to reconcile their status as citizens of their host-country with their support for a cause still criminalized by the authorities. In all three countries I studied, the flag of the host-country was for instance systematically raised alongside the LTTE flag during ceremonies commemorating the LTTE martyrs. ${ }^{18}$ Another striking example was the display, during ceremonies organized near Oxford by a group run by former LTTE combatants, of a red doubledecker London bus with both the UK flag and Tamil nationalist symbols on it. ${ }^{19}$

In conclusion, during and after the war, diaspora activists associated with the LTTE had an ambivalent attitude towards the issue of migrants' broader politicization in their host-country. They were averse to the articulation of the Tamil cause with other political concerns and to the evolution of the Tamil struggle in contact with the hostcountry political arena, but their demands for support and recognition were nonetheless synonymous with the assertion of being host-country political actors with political rights and claims. LTTE diasporic associations therefore promoted a form of political inclusion which did not challenge the primacy of the Tamil cause.

\section{Independent diaspora organizations and the articulation of the Tamil cause with host-country politics}

Independent diasporic organizations, which were not subordinated to the LTTE nor to any other actor based in Sri Lanka, were in contrast most often supportive of a full articulation of the Tamil cause with host-country politics. When, during the war, the LTTE exerted its monopoly over the diasporic political field, these groups were silenced or marginalized, but they reemerged as important actors during the last phase of the war and held a significant position in the post-war period. As mentioned earlier, 2009 represented a major shift in Tamil diaspora politics. Unlike LTTE oversea structures, which primarily focused on collecting funds from migrants for the armed struggle, these new groups dedicated themselves to lobbying international actors to convince them to put pressure on the Sri Lankan government. ${ }^{20}$ While members of TCCs were typically first-generation immigrants who did not necessarily speak the language of their host-country and who often mainly socialized with the Tamil community, these new lobbying organizations were run by individuals who had mastered the hostcountry language, often had high-skilled jobs, and were strongly socialized into their 
host-society (Brun and Van Hear 2011). Many amongst them were young secondgeneration immigrants and, while the old-guard consisted in a large part of high-caste men from the Jaffna peninsula, this second generation of activists was more diverse with, in particular, a much greater number of women. This type of organizations was particularly active in English-speaking countries such as Canada or the UK, where a Tamil educated elite is more present, and which also happen to be multiculturalist political environments where ethnic lobbying is more tolerated. In France, in contrast, the remnants of the LTTE structures remained in a dominant position.

\section{The incorporation of external ideological influences into Tamil nationalism}

Contrary to "purist" LTTE associations, and despite the latter's accusations of political co-optation, these groups departed in important ways from the Tamil nationalist ideology promoted by the LTTE leadership during the war. Through processes of frame broadening, they associated Tamil nationalism with other universalist principles and with other political struggles. This incorporation of external ideological influences had a strategic dimension, but not only that. Tamil lobbying groups strategically adapted the framing of their cause to the cultural and discursive constraints of their political environment in order to increase their access to western decisionmakers. ${ }^{21}$ They downplayed their support for the LTTE and for the separatist cause, and reframed their grievances in terms congruent with the liberal frames of human rights, transitional justice, and democracy-promotion, different groups accepting differing degrees of compromise from the "original" Tamil nationalist ideology (Walton 2014; Nadarajah 2018; Kumar 2018; Orjuela 2018). As explained by a member of the Global Tamil Forum, the organization that most stringently departed from the LTTE's separatist stance:

We decided to align ourselves with the wider international thinking on Sri Lanka.... You can only achieve your political aspirations by aligning your interests with the interests of the wider powers, being India or others. Only then you can find a common ground. It might be a crude way of doing things, but it is the only way. In foreign office in Whitehall, they have very little time for Sri Lanka (interview with a member of the GTF, London, 2016).

But the evolution of activists' conception of the Tamil cause was not only the result of processes of strategic framing; it also involved logics of conviction, the two often being difficult to distinguish. These ideological changes were introduced at least partly as a result of activists' political socialization in their host-country (in school, university, through their involvement in labor unions etc.). Most members of lobbying groups I interviewed explained to me that they adhered to at least some of the universalist values they were adopting, thereby blurring the distinction between instrumental adaptation and ideological evolution of the cause. Several second-generation activists, in particular, stated that the defense of the Tamil cause framed as a promotion of democracy and human rights was for them part of a broader commitment to liberal principles:

Back in 2009, we didn't have the easy access that we do have now. So, there was a necessity of having to compromise, of having to brand ourselves to have the best access, we can't deny that. ... But at the same time, it's not like we don't believe in these things either, you know, human rights, democracy, minority rights... Our engagement, it's also kind of our values, our Canadian identity, you know, what it 
means to be a Canadian, those political values that we hold as Canadians. We do try to take that and import that to how we see issues in Sri Lanka. How we go about it. How it informs it. How it should inform it. It's a bit different from like "I am for Tamil Eelam" in the old LTTE way (interview with a second-generation member of Sri Lankans Without Border, Toronto, 2018).

Some organizations did not articulate their defense of the Tamil nationalist cause with liberal principles dominant in western political environments, but with ideologies that were more marginal among host-country political elites and that therefore had no strategic value for advocacy purposes. A prime example was the British organization Tamil Solidarity, which embraced socialist principles in addition to Tamil nationalism. The group promoted a complete merger of the Tamil cause with a struggle for the rights of workers and oppressed people internationally, without claiming the superiority of one struggle over the other. In Sri Lanka, Tamil Solidarity promoted the creation of an independent socialist Tamil state that would protect the rights of workers and of all ethnic minorities (a strong departure from the official LTTE credo). At the same time, they urged the diaspora to associate its transnational activism with a broader socialist engagement in the UK. In Sri Lanka, they sought to establish connections with socialist Sinhalese actors rather than with conservative Tamil parties, and in their advocacy practices in the UK, they sought support only from leftist politicians to whom they attributed a history of protection of oppressed people, even if the latter's political influence on foreign policy making was limited.

\section{The merger of Tamil nationalism with other political causes}

Then, unlike LTTE activists, many independent advocacy groups did not mobilize exclusively against the oppression of Tamils in Sri Lanka. They also fought for the rights of Tamil migrants themselves, opposed different forms of oppression within the Tamil diaspora itself, and participated in mainstream host-country politics. Firstly, in their lobbying actions, some Canadian and British activists mixed their demands to put pressure on Sri Lanka with claims pertaining to the social, economic, or legal situation of Tamil migrants themselves. In Toronto, for example, one of the major issues taken up by lobbyists was mental health and drugs addiction, given the high rate of psychological disorder among Tamil war refugees. ${ }^{22}$ Activists developed a rationale according to which the homeland and immigrant politics were tightly articulated. As explained by a member of the CTC, "The underlying ideology of the CTC is somehow that you need to be strong here in order to be effective there, and given the number of people we have here, and the level of permanency, I think that is understood" (interview with the CTC president, Toronto, 2018). This stance was echoed by members of Tamil Solidarity in the UK:

The problems in Sri Lanka are not going to be settled anytime soon. So, what do you do? Do you give people a dream of an imaginary homeland, that they won't have? Or you politicize them to defend their rights here? And through that, it will give the opportunity, and energy and hope to the people who are struggling there. If you become a slave here, do you think they're going to fight there? So, you have to free yourself first. So, we want to defend our rights here ... And not only defend Tamil Eelam there (interview with a member of Tamil Solidarity, London, 2017).

Secondly, while LTTE diaspora activists considered discussions about the internal problems the Tamil community was facing-such as gender or caste discrimination-as weakening the nationalist struggle and argued for them to be postponed till after 
independence, these issues were vividly addressed by some second-generation advocacy groups committed to opposing different kinds of oppression.

Thirdly and finally, members of lobbying organizations articulated their mobilization for the Tamil cause with an engagement in the political affairs of their host-country. They regularly took public positions on political issues debated in their country of residence and brought their support to other struggles for emancipation. In Canada, for example, of particular concern to Tamil activists were the rights of indigenous populations. As explained by a second-generation member of the organization Sri Lankans Without Borders (SLWB):

We do try to remain aware, vigilant of issues that face Canada as well, and make like those links with Tamil issues. So, for example, Canada right now is in the midst of a reconciliation with these indigenous communities. You can make a lot of links back to the situation in Sri Lanka, right? It's important to us to be aware of that and to try to incorporate that in what we do here. Because we are a community of Canadians first. So, when it comes to the issues that resonate with our mission in Sri Lanka, like indigenous rights, we can make public statements on social media, or share videos... (Interview with a second-generation member of Sri Lankans Without Border, Toronto, 2018).

This concern was echoed by a former CTC member:

The issue that we are confronting is that Canada is a settler society, founded on the backs of the indigenous people, and while it wasn't the Tamils that came 400 years ago, Tamils benefit from that colonial experience. So, for me it is important to play a part in that, talk about self-determination for them too. I'm always conscious of what Canada Day means for those whose lives were destroyed. Tamil organizations should engage in that too (Interview with a former member of the CTC member, Toronto, 2018).

Some Tamil activists also took a stance for causes that shared few similarities with the Tamil nationalist struggle, such as when the CTC marched with Gay Pride in Toronto. ${ }^{23}$

Tamil Solidarity was one of the post-war organizations that most actively took part in the politics of its host-country. It joined protests against a wide range of domestic issues, such as budget cuts in the National Health Service (NHS), environmental degradations, racism, immigration laws etc. In the words of a leading member:

There is absolute clarity about these engagements. Before, Tamils would never take part in protests here. We changed that. Now you can't find any protest in the country where there are not at least 20 Tamils. The organizers also ask us to be speakers, for example for the anti-racism demonstration. We were actually the only people who organized the "Stop the Bombing in Syria." None of the left did it, and then they joined us. So, we are really part of the struggles that are taking place here. Which is not the case in France. If we were in France, we would take an active part in the struggle that is happening now. "Fuck Sirisena ${ }^{24}$ and fuck Macron" would be our slogan (interview with a member of Tamil Solidarity, London, 2017).

The engagement of Tamil Solidarity members in British civil society life also included their support for workers' strikes all around the country and their active participation in British labor unions. This strong political engagement in countries of settlement remained articulated to an assertion of activists' Tamil identity: "We want our members to play leading roles, to be part of the leading feminists in this country. But also without denying our roots and our struggle in Sri Lanka. You don't have to deny your roots to become leading feminists in this country. ... We want to challenge the foundations of the identity" (ibid.), said for instance a member of the group, echoed by another one who stated that "the ultimate conclusion of our movement would be 
Nadesan [a member of the group] becoming prime minister in the UK while building a fight in Sri Lanka" (interview with a member of Tamil Solidarity, London, 2018). The supposed opposition between transnational and homeland political loyalties, assumed by assimilationist approaches, is clearly challenged here.

Tamil Solidarity activists have also been making constant efforts to inform the broader Tamil population in the UK about British politics and to convince them to participate more actively. They broadcasted debates on Tamil TV channels where they explained and defended their stance on different British political issues. A Tamil Solidarity member explained how they were urging groups which adopted an "apolitical" stance to change their approach:

These groups struggle to reach out to the youth, and I mean it's normal. That's why we are pushing the organizations to take up the issues, here. You have to treat them [second-generation Tamils] like British, you can't constantly say "you are a Tamil." They are concerned by the issues here. You can't say "I don't have a position" and then expect them to organize. That's the contradiction that the other organizations don't get. They can't continue to say, "we won't take a position in British politics." They'll lose a generation (interview with a member of Tamil Solidarity, London, 2017).

After the war, this kind of hybrid political engagement became widespread, but it was still controversial and subject to repeated attacks from former LTTE structures. As a result, even when activists assumed their broader politicization, they had to pay attention to maintaining the strict independent status of their organization. In line with these concerns, Tamil Solidarity refused to formally affiliate to the UNISON-the largest British labor union-with which it had close relations. The high interest of the labor union for a migrant organization campaigning to convince South Asian workers to unionize, and the desire of the two groups to formalize their cooperation then led to a rather surprising outcome: the UNISON eventually agreed to affiliate itself to the small Tamil group (thereby endorsing Tamils' right to self-determination) (ibid.).

Another major form of engagement of advocacy organizations in host-country politics was their participation in party politics. Since this aspect was particularly controversial and subject to attacks from purist groups, the attitude of advocacy organizations towards host-country political parties was ambivalent. One tendency was to present themselves as "apolitical" groups, to use a term commonly mentioned by activists to describe an absence of party affiliation, and to give the Tamil nationalist cause primacy over party dynamics. In the UK, the leader of the British Tamils Forum (BTF) for instance insisted on the non-partisan status of the organization and presented the actions of its party-related sub-branches, such as Tamils for Labour or British Tamil Conservatives, ${ }^{25}$ merely as a way to rationalize lobbying efforts:

We are not a particular party support group, we created party support groups, but we don't take a party stance. Tamils for Labour, Tamils Conservatives. We initiated them, all of them, to be more efficient when we approach political parties. But overall, as an umbrella group, the BTF is a politically neutral organization doing lobbying for Tamils in Sri Lanka only (interview with the leader of the BTF, London, 2018).

In line with this "apolitical" approach, some lobbying organizations called Tamil voters abroad to act as a single-issue voting bloc and elect the candidate most supportive of the Tamil cause, regardless of his or her political orientation. Before some elections in the UK, the BTF and the Tamil Guardian interrogated all the candidates about their 
stance on Sri Lanka, and then published a database with their results to guide the electoral choice of Tamil voters (Tamil Guardian 2015). country political parties and most Tamil advocacy organizations. At the individual level, a number of activists were members of a political party. At the organization level, the goal of some lobbying groups was not only to pull party members to the Tamil cause, but also to encourage the promotion of a particular party within the community. Even though they were portrayed by the BTF's leader as just a way to increase the efficiency of the organization's lobbying efforts, the group's party-specific branches actually showed an allegiance to that party, as one could see even on their official webpages. Tamils for Labour for instance presented their mission in the following manner: "Delivering the Tamil Community votes for the Labour Party and a Labour government delivering for the Tamil people" (BTF 2018). The British Tamil Conservatives also presented their objectives as both lobbying the Conservative Party and promoting the party within the Tamil diaspora:

The Tamil community being naturally conservative, with firm belief in tradition, family values and education, we wished to strengthen their relationship with the Conservative Party by forming an organization that can support the party and be a bridge between the community and the conservatives. The British Tamil conservatives are committed to bring awareness of the plight of the Tamils in Sri Lanka within the Conservative party and seek justice, peace and dignity for the Tamil community (BTF 2018).

These groups pointed to the existence of divisions in the Tamil political field along host-country party cleavages. Tamil activists joined them following their own political preferences: an activist for instance explained his recent decision to leave the BTF and work only for Tamils for Labour as due to the conservative opinions of most of the BTF team (interview with a member of Tamils for Labour, London, 2017). Naturally, Tamil Solidarity was also actively engaged in party politics. It was closely linked to-though formally independent of-the Socialist Party, a small Trotskyist party standing with the Trade Unionist and Socialist Coalition for national elections. Many members of Tamil Solidarity were also members of the Socialist Party, and the latter provided the Tamil group with organizational resources, an office, a place for printing etc. (interviews with members of Tamil Solidarity, London, 2017-2018). In 2017, the group also campaigned for Jeremy Corbyn in the UK national elections, both within and outside the Tamil community.

Yet another major aspect of Tamil activists' engagement in party politics was their own participation in the electoral game. Starting in 2007-2008, and increasingly so after the LTTE defeat, numerous Tamil activists campaigned for elections, at the local level in all countries of settlement, and at the national level in the UK and Canada, with the active support of Tamil lobbying groups. A number of them were elected, including in national legislative elections. ${ }^{26}$ In all cases, the resources and skills candidates and 
organizations had developed in their activism for the Tamil cause were transferred to their entry into mainstream electoral politics, similarly to what has been observed by scholars in other cases (Guarnizo, Portes and Haller 2003; Escobar 2004; Portes and Rumbaut 2006; Zederman 2018). Some of these candidates initially run on two parallel programs: one that was focused on the Tamil nationalist cause and was put forward when addressing the Tamil community, and a broader program for the rest of their electorate (see for instance Tamilnet 2009).

For several candidates I interviewed, the Tamil cause was an important element in their candidacy. Standing for elections was often presented by themselves or by the Tamil organizations supporting them as a platform to promote the cause. Yet, especially when candidates were nominated by a political party, and then a fortiori when they were in office, their Tamil nationalist engagement was overshadowed by their implication in host-country political affairs. According to the Tamil Canadian MP Gary Anandasangaree:

I think even those who use that [the Tamil cause] to promote themselves, they quickly realize that it can't be a path to electoral office. And it's not really the reason why they run for elections. I think it's a facade. I think they are interested in politics, elections and power and use that as a vehicle to power (interview with Gary Anandasangaree, Canadian MP, Toronto, 2018).

National considerations could even lead elected Tamil activists to distance themselves from Tamil nationalism. For example, Vijay Thanigasalam, a member of the National Council of Canadian Tamils (NCCT) who was elected to the Legislative Assembly of Ontario in the 2018 provincial elections, had to publicly apologize for Facebook posts supporting the LTTE (Bell 2018). In a similar perspective, Anandasangaree explained that in the Canadian context, with Quebec nationalism being such a sensitive issue, openly supporting Tamil separatism was very delicate for him, but that he remained committed to that initial mission of his. Even though the host-country political environment itself might not favor the merger of diaspora politics with a broader politicization, many diaspora activists remain committed to articulating the two. This is a commitment that clearly appears in the way the MP Anandasangaree summarized his mission as an elected Tamil nationalist activist: "I have two kinds of responsibilities. It's one thing to advance the Tamil issue to the front stage, and it's also my responsibility to advance this community to broader values, to broader perspectives of life." (ibid.).

\section{Conclusion}

47 In conclusion, the engagement of Tamil migrants in the national liberation movement in Sri Lanka by and large favored their assertion as actors with political agency in their country of settlement, but through different pathways depending on the organizations. While diaspora politics and migrants' inclusion in host-country politics did not appear as a zero-sum game, the association of Tamil national politics with other political influences and concerns was, nonetheless, a highly controversial issue in the diasporic political field, some activists seeing in these dynamics a risk of co-optation and dilution of the Tamil cause. The political activism of diasporic organizations subordinated to the LTTE during the war, and then claiming to be their successors after the war, was based on the idea of a primacy and exclusivity of the Tamil nationalist cause and on a rejection of external ideological influences. It was associated to a moral economy that 
depreciated political engagements disconnected from the cause and hostile to the broader political inclusion of Tamil migrants in their host-country along these lines. But these activists' demands for support for their separatist cause and their increasingly important engagement in recognition politics nonetheless led to their political assertion in their countries of settlement. This process constituted a form of political inclusion compatible with the primacy of the Tamil nationalist cause. In contrast, independent Tamil organizations departed from this exclusionary approach and promoted a full articulation of the Tamil nationalist cause with other political concerns. These groups, which were marginalized during the war when the LTTE dominated diasporic political spaces, became significant after the movement's defeat in 2009 and with the coming of age of second-generation migrants. They incorporated external ideological influences in their conception of the Tamil struggle and merged their commitment to homeland politics with a broader engagement in host-country politics. They left aside the guilt that some activists seemed to feel when deviating from the nationalist cause. For all that, their political socialization in their host-country did not lead them to stop their homeland-oriented activism. In addition to confirming the point that transnational political practices can be a vector for migrants' political inclusion, the case of Tamil diaspora politics shows that the modalities of incorporation of diaspora activists into host-country politics can be a major stake for them, leading to thorough reflections about their role as migrant political actors, to deep disagreements between various poles of a diasporic field, and to diverse pathways of insertion in the host-country political arena.

\section{BIBLIOGRAPHY}

Amarasingam, Amarnath. 2015. Pain, Pride and Politics: Social Movement Activism and the Sri Lankan Tamil Diaspora in Canada. Athens, Georgia: The University of Georgia Press.

Anderson, Benedict. 1998. "Longdistance Nationalism: World Capitalism and the Rise of Identity Politics." Pp. 58-74 in The Spectre of Comparisons: Sationalism, Southeast Asia and the World, edited by B. Anderson. London: Verso.

Baser, Baher. 2015. Diasporas and Homeland Conflicts: A Comparative Perspective. Routledge.

Bauböck, Rainer, Albert Kraler, Marco Martiniello, and Bernhard Perchinig. 2006. “Migrants' Citizenship: Legal Status, Rights and Political Participation.” Pp. 65-98 in The Dynamics of International Migration and Settlement in Europe, edited by R. Penninx, M. Berger, and K. Kraal. Amsterdam, The Netherlands: Amsterdam University Press.

Bell, Stewart. 2018. "Ontario PC Candidate Apologizes for Facebook Posts Praising Terrorist Group.” Global News, June 6. Retrieved November 24, 2021 (https://globalnews.ca/news/4256193/ ontario-pc-candidate-apologizes-facebook-posts-terrorist/).

Berger, Maria, Christian Galonska, and Ruud Koopmans. 2004. "Political Integration by a Detour? Ethnic Communities and Social Capital of Migrants in Berlin." Journal of Ethnic and Migration Studies 30(3):491-507.

South Asia Multidisciplinary Academic Journal, 27 | 2021 
Brubaker, Rogers. 2005. “The 'Diaspora' Diaspora.” Ethnic and Racial Studies 8(1):1-19.

Brun, Cathrine and Nicholas Van Hear. 2012. "Between the Local and the Diasporic: The Shifting Centre of Gravity in War-torn Sri Lanka's Transnational Politics." Contemporary South Asia 20(1): 61-75.

BTF (British Tamils Forum). 2018. “Our Team.” United Kingdom: British Tamils Forum. Retrieved June 2, 2021 (https://www.britishtamilsforum.org/about-2/our-team-2/).

Cain, Bruce E. and Brendan J. Doherty. 2006. “The Impact of Dual Nationality on Political Participation." Pp. 89-105 in Transforming Politics, Transforming America: The Political and Civic Incorporation of Immigrants in the United States, edited by T. Lee, S. K. Ramakrishnan and R. Ramirez. Charlottesville: University of Virginia Press.

Chalk, Peter. 2008. "The Tigers Abroad: How the LTTE Diaspora Supports the Conflict in Sri Lanka." Georgetown Journal of International Affairs 9(2):97-104.

Contamin, Jean-Gabriel. 2010. “Cadrages et luttes de sens.” Pp. 55-75 in Penser les mouvements sociaux, edited by E. Agrikoliansky, I. Sommier and O. Fillieule. Paris: La Découverte "Recherches."

Dequirez, Gaëlle. 2011. "Nationalisme à longue distance et mobilisations politiques en diaspora. Le Mouvement séparatiste tamoul sri lankais en France (1980-2009).” PhD Dissertation, University of Lille II.

Dequirez, Gaëlle. 2007. “Tamouls sri lankais: le Little Jaffna de La Chapelle.” Hommes et migrations 1268-1269:82-91.

Dusenbery, Verne A. 1995. “A Sikh Diaspora? Contested Identities and Constructed Realities." Pp. 17-42 in Nation and Migration, edited by P. Van der Veer. Philadelphia: University of Pennsylvania Press.

Escobar, Christina. 2004. "Dual Citizenship and Political Participation: Migrants in the Interplay of United States and Colombian Politics." Latino Studies 2(1):45-69.

Étiemble, Angélina. 2017. “Tamouls du Sri Lanka en France. Politisation de l'exil dans l'ombre des Tigres.” Revue européenne des migrations internationales 33(4).

Étiemble, Angélina. 2004. "Les Tamouls du Sri Lanka dans la région parisienne: l'emprise du politique." Revue française des affaires sociales 2:145-64.

Fassin, Didier and Jean-Sébastien Eideliman, eds. 2012. Économies morales contemporaines. Paris: La Découverte.

Fuglerud, Øivind. 1999. Life on the Outside: The Tamil Diaspora and Long-distance Nationalism, London: Pluto Press.

Gayer, Laurent. 2000. “The Globalization of Identity Politics: The Sikh Experience.” International Journal of Punjab Studies 7:223-62.

Gazagne, Philippe and Amaia Sánchez-Cacicedo. 2015. "Understanding the Politics of the Sri Lankan Tamil Diaspora in Switzerland." Global Migration Research Paper No.14.

Guribye Eugene. 2013. “'Quislings': Barriers to Linking Social Capital Amongst Members of ProLiberation Tigers of Tamil Eelam Non-Governmental Organizations in Norway in a Post-Conflict Situation." Journal of Civil Society 9(3):233-47. 
Gershon, Sarah A. and Adrian D. Pantoja. 2014. "Pessimists, Optimists, and Skeptics: The Consequences of Transnational Ties for Latino Immigrant Naturalization." Social Science Quarterly 95(2):328-42.

Giugni, Marco and Laura Morales. 2011. Social Capital, Political Participation and Migration in Europe: Making Multicultural Democracy Work? United Kingdom: Palgrave Macmillan.

Guarnizo, Luis E., Alejandro Portes, and William J. Haller. 2003. “Assimilation and Transnationalism: Determinants of Transnational Political Action among Contemporary Immigrants." American Journal of Sociology 108(6):1211-48.

Grojean, Olivier. 2008. "La Cause kurde, de la Turquie vers l'Europe. Contribution à une sociologie de la transnationalisation des mobilisations." PhD Dissertation, EHESS, Paris.

Guyot, Lola. 2020. "Les Pratiques répressives des LTTE. Dispositifs spatialisés de purification de la nation tamoule.” Pôle Sud 53(2):101-15.

Hellgren, Zenia. 2015. "Immigrant Integration as a Two-Way Process: Translating Theory into Practice.” Working Paper No. 23. Barcelona, Spain: Gritim-Universitat Pompeu Fabra.

Hess, Monika, and Benedikt Korf. 2014. "Tamil Diaspora and the Political Spaces of Secondgeneration Activism in Switzerland." Global Networks 14(4):419-37.

Huntington, Samuel P. 2004. Who Are We? The Challenges to America's National Identity. New York: Simon \& Schuster.

ICG (International Crisis Group). 2010. “The Sri Lankan Tamil Diaspora after the LTTE.” International Crisis Group, Asia Report No. 186.

Jayasekara, Shanaka. 2009. “Cornered Tigers: The LTTE Evolves as Guerrillas.” Jane's Intelligence Review 21(4):12-15.

Kandasamy, Niro. 2020. "Home, Continuities and Resistance: Memory Activism in the Aftermath of Sri Lanka's Civil War.” Pp. 53-70 in A Sense of Viidu: The (Re)creation of Home by the Sri Lankan Tamil Diaspora in Australia, edited by N. Kandasamy, N. Perera and C. Ratnam. Singapore: Palgrave Macmillan.

Koinova, Maria. 2011. "Can Conflict-Generated Diasporas be Moderate Actors during Episodes of Contested Sovereignty? Lebanese and Albanian Diasporas Compared." Review of International Studies 37:437-62.

Koinova, Maria. 2010. "Diasporas and International Politics: Utilizing the Universalistic Creed of Liberalism for Particularistic and Nationalist Purposes." Pp. 149-66 in Diaspora and Transnationalism: Concepts, Theories and Methods, edited by R. Bauböck and T. Faist. Amsterdam: Amsterdam University Press.

Kumar, Priya. 2018. "Rerouting the Narrative: Mapping the Online Identity Politics of the Tamil and Palestinian Diaspora." Social Media + Society.

Lacroix, Thomas. 2019. "Transferts migratoires, institutions sociales migrantes et territorialité morale transnationale." L'Espace Politique 38(2).

Lacroix, Thomas. 2005. “L'Engagement citoyen des Marocains de l'étranger. Les Migrants et la démocratie dans les pays d'origine." Hommes \& Migrations 1256:89-102.

Lacroix, Thomas, and Elena Fiddian-Qasmiyeh. 2013. "Refugee and Diaspora Memories: The Politics of Remembering and Forgetting." Journal of Intercultural Studies 34(6):684-96. 
Laffey, Mark, and Suthaharan Nadarajah. 2012. "The Hybridity of Liberal Peace: States, Diasporas and Insecurity." Security Dialogue 43(5):403-20.

Massicard, Elise. 2013. "Quand le militantisme s'adapte au terrain. Continuités et discontinuités dans les carrières militantes au sein du mouvement aléviste en Turquie et en Allemagne." Politix 102(2):89-108.

Massicard, Elise. 2007. "Le Poids du local dans les configurations associatives des alévis en Europe." Pp. 57-68 in Migrations turques dans un monde globalisé. Le poids du local, edited by A. Y. Guillou, S. de Tapia and P. M. Wadbled. Presses Universitaires de Rennes.

Mcdowell, Christophe. 1996. A Tamil Asylum Diaspora: Sri Lankan Migration, Settlement and Politics in Switzerland. Oxford: Berghahn Books.

Morales, Laura and Miruna Morariu. 2011. “Is 'Home' a Distraction? The Role of Migrants' Transnational Practices in Their Political Integration into Receiving-Country Politics." Pp. 140-71 in Social Capital, Political Participation and Migration in Europe, edited by L. Morales and M. Giugni. United Kingdom: Palgrave Macmillan.

Nadarajah, Suthaharan. 2009. "Disciplining the Diaspora: Tamil Self-Determination and the Politics of Proscription." Pp. 109-30 in Spaces of Security and Insecurity: Geographies of the War on Terror, edited by A. Ingram and K. Dodds. Farnham, UK: Ashgate.

Nadarajah, Suthaharan. 2018. "The Tamil Proscriptions: Identities, Legitimacies, and Situated Practices." Terrorism and Political Violence 30(2):278-97.

O'Neill, Tom. 2015. "In the Path of Heroes: Second-generation Tamil-Canadians after the LTTE" Identities: Global Studies in Culture and Power 22(1):124-39.

Orjuela, Camilla. 2020. "Passing on the Torch of Memory: Transitional Justice and the Transfer of Diaspora Identity across Generations." International Journal of Transitional Justice 14(2):360-80.

Orjuela, Camilla. 2018. "Mobilising Diasporas for Justice. Opportunity Structures and the Presencing of a Violent Past." Journal of Ethnic and Migration Studies 44(8):1357-73.

Orjuela, Camilla. 2008. "Distant Warriors, Distant Peace Workers? Multiple Diaspora Roles in Sri Lanka's Violent Conflict.” Global Networks: A Journal of Transnational Affairs 8(4):436-52.

Østergaard-Nielsen, Eva. 2003. Transnational Politics: Turks and Kurds in Germany. London: Routledge.

Penninx, Rinus, and Blanca Garcés-Mascareñas. 2016. "The Concept of Integration as an Analytical Tool and as a Policy Concept." Pp. 11-29 in Integration Processes and Policies in Europe: Contexts, Levels and Actors, edited by B. Garcés-Mascareñas and R. Penninx. New-York, USA: Springer International Publishing.

Pereira, Victor. 2012. La Dictature de Salazar face à l'émigration. L'Etat portugais et ses migrants en France, 1957-1974. Paris: Les presses de Sciences Po.

Portes, Alejandro, and Rubén G. Rumbaut. 2006. Immigrant America: A Portrait. Berkeley: University of California Press.

Rasaratnam, Madurika. 2016. Tamils and the Nation: India and Sri Lanka Compared. USA: Oxford University Press.

Seoighe, Rachel. 2017. War, Denial and Nation-Building in Sri Lanka: After the End. London: Palgrave, Macmillan. 
SOAS (School of Oriental and African Studies). 2020. "Support Tamil Studies at SOAS." United Kingdom: School of Oriental and African Studies. Retrieved June 2, 2021 (https:// soas.hubbub.net/p/TamilStudies/pitch/).

Sökefeld, Martin. 2006. "Mobilizing in Transnational Space: A Social Movement Approach to the Formation of Diaspora." Global Networks 6(3):265-84.

Sriskandarajah, Dhananjayan. 2005. “Tamil Diaspora Politics.” Pp. 493-501 in Encyclopedia of Diasporas: Immigrant and Refugee Cultures Around the World, edited by M. Ember, C. R. Ember, and I. Skoggard. New Haven, CT: Yale/Kluwer.

Staton, Jeffrey K., Robert A. Jackson, and Damarys Canache. 2007. "Dual Nationality Among Latinos: What Are the Implications for Political Connectedness?" Journal of Politics 69(2):470-82.

Stora, Benjamin. 1992. Ils venaient d'Algérie. L'Immigration algérienne en France (1912 1992). Paris: Fayard.

Tamil Culture. 2016. "January is Officially Declared as Tamil Heritage Month in Canada." Tamil Culture, October 5. Retrieved June 2, 2021 (https://tamilculture.com/january-officially-declaredtamil-heritage-month-canada/).

Tamil Guardian. 2015. "UK Parliamentary Candidates Detail Their Views on the Tamil Question." Tamil Guardian, May 7, 2015. Retrieved June 2, 2021 (http://www.tamilguardian.com/article.asp? articleid=14626).

Tamilnet. 2009. “Potent Tamil Voice for European Parliament." Tamilnet, May 31. Retrieved June 2, 2021 (http://www.tamilnet.com/art.html?catid=13\&artid=29493).

Thiranagama, Sharika. 2014. "Making Tigers from Tamils: Long-Distance Nationalism and Sri Lankan Tamils in Toronto." American Anthropologist 116(2):265-78.

Thurairajah, Kalyani. 2013. “Caught Between the 'Bleeding Homeland' and the 'Safe Haven': Negotiating Loyalties in Times of Conflict.” PhD Dissertation, McGill University, Montreal.

University of Toronto Scarborough. 2020. "University of Toronto Chair in Tamil Studies." Canada: University of Toronto Scarborough. Retrieved June 2, 2021 (https://www.utsc.utoronto.ca/ alumni/university-toronto-chair-tamil-studies).

Vimalarajah, Luxshi, and R. Cheran. 2010. "Empowering Diasporas: The Politics of Post-war Transnational Tamil Politics.” Berghof Peace Support Occasional Paper No. 31.

Waldinger, Roger, and Lauren Duquette-Rury. 2016. "Emigrant Politics, Immigrant Engagement: Homeland Ties and Immigrant Political Identity in the United States." The Russell Sage Foundation Journal of the Social Sciences 2(3):42-59.

Walton, Oliver. 2015. "Framing Disputes and Organizational Legitimation: UK-based Sri Lankan Tamil Diaspora Groups' Use of the 'Genocide' Frame since 2009.” Ethnic and Racial Studies 38(6): 959-75.

Wayland, Sarah. 2004. "Ethnonationalist Networks and Transnational Opportunities: The Sri Lankan Tamil Diaspora." Review of International Studies 30(3):405-26.

Westby, David L. 2002. “Strategic Imperative, Ideology, and Frame.” Mobilization: An International Journal 7(3):287-04.

Zederman, Mathilde. 2018. "Trans-state Spaces of Mobilization: Tunisian Activism in France in the Era of Ben Ali (1987-2011).” PhD Dissertation, SOAS, University of London. 


\section{NOTES}

1. The concept of "diaspora politics" refers to the engagement of migrants and their descendants in the political affairs of their homeland. The term "diaspora" will be used in the paper as a "category of self- and other-identification in practice" (Brubaker 2012:6) referring to a transnational imagined community.

2. Koinova for instance showed that diaspora activists engaged in separatist struggles tend to strategically "utilize the universalistic creed of liberalism for particularistic and nationalist purposes" (Koinova 2010:149).

3. The content of these norms and causes, which can be dominant or marginal in the hostsociety, does not matter.

4. This includes any form of political participation, in elections but also in social movements or interest group politics.

5. It its most extreme form, present in extreme-right discourses, this approach materializes into suspicion of a lack of allegiance of migrants with transnational ties to their country of residence and into the spectrum of a fifth column.

6. As explained by Zederman (2018), this chronological evolution can be due to several factors, such as a provisionary decline of the myth of return, a greater inclusion in the host-society, a socialization with other immigrant political actors, or a greater opportunity for immigrant politics when the disapproval of transnational practices by host-country authorities and the repression at home hinder diaspora politics.

7. That is to say the set of negotiated norms establishing the rights and duties of interacting social classes (Fassin and Eideliman 2012).

8. From the early 1990s, Tamils overseas became the dominant source of funding for the LTTE, and their financial contributions proved decisive in the successes and resilience of the insurgent movement. The exact amount of funds raised in the diaspora is impossible to determine, but some estimations indicate that by the mid-1990s, 80 to $90 \%$ of the LTTE military budget came from overseas resources (Jane Intelligence 2007; Chalk 2008).

9. Some independent organizations run by activists critical of the LTTE, such as the Tamil Information Centre in the UK, the Tamil Resource Centre in Canada, and the group around Shoba Sakhti in France, continued to exist but, due to pressures and threats from TCC activists, they were confined to a marginal position in the diasporic political field and constrained to downplay their criticisms of the LTTE.

10. At its head was the International Secretariat, which was first based in London, then in Paris, before being brought back to Sri Lanka. The national branches, the TCCs, unofficially supervised a vast network of local associations, such as neighborhood, youth, women or sport associations.

11. The term encadrement, which is difficult to translate into English, reflects a mixture of social control and surveillance with social and administrative support (Pereira 2012; Zederman 2018).

12. Some of these organizations were created a few years before the end of the war, but became truly active and independent from the TCCs in 2009.

13. The interviews, which were recorded, lasted between one and four hours and were conducted in English, in French, or in Tamil, with an interpreter brought by the interviewee. About two thirds of my interviewees were first-generation migrants, and the remaining third secondgeneration migrants who had in general become strongly politically active in the wake of the LTTE's defeat. While among first-generation migrants, the vast majority of my interviewees were males, reflecting the marginalization of women in the political organizations of this generation, a large proportion of the second-generation activists I interviewed were women.

14. As Dequirez pointed out, "if they had really wanted the support of powerful countries, the Tigers would have made at least minimal changes to meet international standards." (2011:291, translated from French). 
15. As shown by Laffey and Nadarajah (2012) and Nadarajah (2018), the foundations of Tamil nationalism were associated with terrorism and perceived as incompatible with western liberal values.

16. As noted by Westby (2002), when social movement actors cling on to a rigid ideological doctrine, strategic considerations are often denounced as apostasy.

17. In her analysis of the framing practices of LTTE associations abroad, Dequirez (2011) showed that when they addressed a non-Tamil audience, the strategic framing processes adopted by LTTE diasporic association were limited to concealing the most bellicose aspect of the LTTE rhetoric and insisting on the status of victims of Tamils in Sri Lanka.

18. A high-ranking member of an LTTE association in London explained to me that the decision to systematically raise the British flag in these events was taken after heated debates in 2008 (interview conducted in 2018).

19. On the bus, which belonged to a British Tamil running a driving school, was depicted a heart filled with the British flag on one side and the LTTE flag on the other side, on which was written "Tamil Eelam" and "Be proud to be British."

20. These new groups include the British Tamils Forum (BTF) and Tamil Solidarity in the UK, the Canadian Tamil Congress (CTC) and the National Council of Canadian Tamils (NCCT) in Canada, the Maison du Tamil Eelam (MTE) in France, the Swiss Tamil Forum, the Swedish Tamil Forum, the Norwegian Council of Eelam Tamil (NCET), as well as transnational organizations such as the Global Tamil Forum (GTF) and the Transnational Government of Tamil Eelam (TGTE).

21. This kind of discursive strategy is not specific to diaspora activists. Scholars of social movement theory have shown that social movement entrepreneurs strategically frame their grievances and demands in order to increase their resonance amongst targeted audiences. The framing of a cause can then be seen as the result of combined efforts to stay loyal to the core ideological commitments of the movement while strategically adapting to dominant discourses in a given political environment (Westby 2002; Contamin 2010).

22. They demanded state subventions as well as additional medical facilities in neighborhoods with a large Tamil population (interviews with members of the CTC, Toronto, 2018).

23. This particularly controversial decision, given the conservative values embraced by many Tamil migrants, stemmed from the efforts of one member of the CTC who was actively engaged in LGBTQ+ struggles and successfully convinced the other members of the group to join the event.

24. Sri Lanka's president in 2015-2019.

25. The major lobbying organizations in Canada, the UK and the US established sub-branches tasked with putting pressure on a particular political party. In Canada, we can mention the Canadian Tamil Conservative Association or Tamils for Trudeau and Friends. In the US, such groups included Tamils for Obama and Tamils for Trump.

26. The first Tamil candidate to be elected in national elections was Rathika Sitsabaiesan, former vice president of the Tamil Student Association of Toronto. She became a New-Democrat MP in the House of Commons of Canada for the circumscription of Scarborough-Rouge River, which has a Tamil speaking population of $13 \%$, and a population of "visible minorities" of $90 \%$, the highest amongst all electoral districts in the country. In 2015, another Tamil activist, Gary Anandasangaree, member of the Canadian Tamil Congress, was elected as MP for ScarboroughRouge Park, an adjacent district which also has a large Tamil population. 


\section{ABSTRACTS}

Tamil diaspora political mobilization against the Sri Lankan government shows that, contrary to a commonly held view, migrants' transnational political engagement can be a vector, rather than an obstacle, to their political inclusion in their country of settlement. But the articulation of a homeland-oriented struggle with the broader political participation of migrants has been a highly contentious issue in the diasporic political field, some activists seeing in these dynamics a risk of co-optation and dilution of the Tamil cause. While LTTE diasporic associations promoted a form of political inclusion which did not challenge the primacy of the Tamil cause, independent diasporic groups incorporated external ideological influences in their conception of the Tamil struggle and merged their homeland-oriented activism with a broader engagement in hostcountry politics. The case of Tamil diaspora politics shows that the modalities of incorporation of diaspora activists into host-country politics can be a major stake for them, leading to thorough reflections about their role as migrant political actors, to deep disagreements between various poles of a diasporic field, and to diverse pathways of insertion in the host-country political arena.

\section{INDEX}

Keywords: Sri Lankan civil war, Tamil diaspora, diaspora politics, immigrant politics, political inclusion

\section{AUTHOR}

\section{LOLA GUYOT}

Sciences Po, Lille; Centre d'études et de recherches administratives politiques et sociales (CERAPS); Institut Convergences Migrations (ICM) 